\title{
Influence of monsoons and oceanographic processes on red tides in Hong Kong waters
}

\author{
Kedong Yin ${ }^{1,2,3, *}$ \\ ${ }^{1}$ Key Laboratory of Tropical Marine Environmental Dynamics, South China Sea Institute of Oceanology, \\ Chinese Academy of Sciences, Guangzhou, PR China \\ ${ }^{2}$ Department of Biology, Hong Kong University of Science and Technology, Clear Water Bay, Kowloon, Hong Kong SAR \\ ${ }^{3}$ Present address: AMCE (Atmospheric, Marine and Coastal Environment) Program, Hong Kong University of Science and \\ Technology, Clear Water Bay, Kowloon, Hong Kong SAR
}

\begin{abstract}
Hong Kong waters in the northern part of the South China Sea are subjected to seasonal oceanographic processes due to monsoonal winds and Pearl River outflow. Several 100 red tides have occurred in Hong Kong waters during 1983 to 1998, and show a clear spatial and temporal distribution. Most $(74 \%)$ occurred in semi-enclosed NE bays away from the Pearl River estuary, and fewer occurred in western estuarine waters. Most red tides (70\%) occurred between December and May, and fewer in summer. However, nutrients are high in the Pearl River estuary, whereas nutrients are generally low in the NE bays (Mirs Bay and Port Shelter) and cannot support the high biomass of red tides. This suggests that there are concentrating mechanisms promoting the formation of red tides in NE waters, either by vertical migration or horizontal aggregation under suitable wind conditions (NE winds and moderate speeds around $6 \mathrm{~m} \mathrm{~s}^{-1}$ ). The prevailing NE monsoon winds in winter and spring result in downwelling and a longer residence time of waters in the NE bays, creating conditions similar to those of a batch culture, and allowing local inputs of nutrients and vertical migration of phytoplankton in shallow waters to play a dominant role in favor of local red tides. This may be one of the reasons why more red tides occur in winter and spring in semi-enclosed waters. In summer, the SW monsoon winds result in upwelling along the coast, and high river discharge and rainfall cause an increased estuarine circulation in the Pearl River estuary and rapid outflow of the surface water from these semi-enclosed waters. As a result, residence time of these waters decreases, and they may be analogous to semi-continuous or continuous cultures. This may explain why there are fewer red tides in summer. The species occurring most frequently are (in descending order) Noctiluca scintillans, Gonyaulax polygramma, Skeletonema costatum, Mesodinium rubrum, Prorocentrum minimum and Ceratium furca. In general, dinoflagellate red tides occur mostly in April when $\mathrm{Si}$ is low, whereas diatom red tides occur in June when Si increases due to the freshwater discharge. Deep oceanic water on the continental shelf is drawn into the NE bays during the upwelling; it is poor in nutrients, and does not favor nutrient acquisition in deep water by vertical migrating dinoflagellates.
\end{abstract}

KEY WORDS: Red tides - HABs · Eutrophication - Monsoons · Winds · Nutrients - Water quality · Hong Kong $\cdot$ Pearl River estuary

Resale or republication not permitted without written consent of the publisher

\section{INTRODUCTION}

Harmful algal blooms (HABs) have become widespread on a global scale (GEOHAB 1998). On the east coast of North America, HABs include the toxic Alexandrium sp. (Anderson D. M. 1997), the brown tide species Aureococcus anophagefferens (Beltrami \&
Cosper 1993, Bricelj \& Lonsdale 1997), and Gymnodinium breve blooms (Tester \& Steidinger 1997, Walsh $\&$ Steidinger 2001). On the west coast, there are Heterosigma blooms in British Columbia (Taylor \& Haigh 1993) and other toxic species (Horner et al. 1997). In Europe, HABs include Gyrodinium aureolum in Norwegian waters monitored for over a 25 yr period (Dahl 
\& Tangen 1993), Alexandrium and Dinophysis along the Catalan coast in the NW Mediterranean Sea (Vila et al. 2001), and Gyrodinium aureolum, Ceratium spp. and Chrysochromulina polylepis in the Skagerrak (Lindahl 1993) and in the Bulgarian Black Sea during 1987 to 1997 (Velikova et al. 1999). HABs frequently occur in the upwelling regions off South Africa (Pitcher \& Calder 2000), in the Mexican Pacific coastal waters (Hernandez-Becerril et al. 2000), in Russian Far Eastern seas and adjacent Pacific areas over the period from the 1920s to the 1990s (Konovalova 1999), and in the Indo-Pacific (MacLean 1989) as well as along the coast of China (Qi et al. 1993).

Numerous mechanisms have been proposed to explain the formation of harmful algal blooms. Basically, a harmful algal bloom is the result of phytoplankton accumulation and species promotion, which depends on growth and loss of phytoplankton cells. Therefore, a bloom of a species depends on abiotic factors such as light, temperature, salinity, turbulence and nutrients for growth, and the bloom also depends on biotic factors such as species competition and differential grazing at physiological, cellular, population, community and ecosystem levels for the species promotion (ECOHAB 1995). The physical (horizontal and vertical) mixing processes not only determine the stability or residence time of the surface layer, but also change the optima of light, salinity, temperature and nutrient concentrations which influence the dominance of a species during the mixing process. Biological behaviors of algae including vertical migration and aggregation under certain matching physical processes and conditions are an important concentration mechanism in the formation of red tides. These mechanisms may operate during different times and at different places for different species.

Nutrient enrichment in coastal waters is generally regarded as a major cause for an increased number of red tide occurrences. However, there are really no data to demonstrate the direct relationship between the two in a linear fashion. In many places, the input of nutrients has increased, resulting in increased nutrient concentration. However, these levels are not high enough to cause high phytoplankton biomass, at least not to the level of red tides, based on the mass balance between inorganic and organic matter. This suggests that there must be aggregation mechanisms for the formation of red tides through physical or biological processes or both. The spatial and temporal distribution of red tides in Hong Kong waters appears to represent a good case for this notion.

Hong Kong is situated on the south coast of China, facing the northern part of the South China Sea, and lying to its west is the Pearl River estuary. Thus, its coastal environments are profoundly influenced by 3 water regimes: estuarine waters in the Pearl River estuary, oceanic waters from the South China Sea and coastal waters from the China Coastal Current to the east. These influences are dependent on 2 seasonal monsoons. In winter, the northeast monsoon prevails and the coastal waters of Hong Kong are dominated by the China Coastal Current (Watts 1971, 1973). In summer, the southwest monsoon blows and transports oceanic waters from the South China Sea onto the continental shelf. The Pearl River discharge reaches a maximum (Zhao 1990) and annual rainfall is highest during summer. The coastal waters of Hong Kong become very dynamic due to advection, mixing and the interaction between freshwater from the Pearl River/runoff and oceanic waters from oceanic currents. Therefore, water circulation and stratification in local water bodies are influenced by these processes, depending on their geographic locations. Hence, there are strong spatial and seasonal changes in stratification, salinity, temperature and nutrients in Hong Kong waters. This offers a unique opportunity to study how red tides are related to environmental processes and conditions.

Red tides have frequently occurred in the Hong Kong territorial waters in the past $20 \mathrm{yr}$, at least 20 red tides occur on average each year (EPD 1998). Red tides not only impose a serious threat to fish farms, but also force the closure of public beaches in Hong Kong (Wong \& Wu 1987, Wong 1989). In 1988, there were large numbers of red tides (EPD 1998) and in 1998, there were massive fish kills during spring due to harmful algal blooms (Yin et al. 1999). The frequency of red tides in these waters has been suggested to be related to an increase in the human population (Lam \& Ho 1989), nutrient inputs (Holmes 1988, Wong 1989) and N:P ratios (Hodgkiss \& Ho 1997). However, the cause of red tides is still controversial (Yung et al. 1997). In Hong Kong, there has been a monitoring program for red tides since the 1980s and water quality has also been monitored since the 1990s. These time series allow us to examine the spatial and temporal distribution of red tides and to make links to environmental conditions. The objectives of this study are (1) to characterize the temporal and spatial distribution of red tides, and (2) to examine whether there is a general pattern of red tide occurrences related to the monsoon events and coastal oceanographic processes and environmental factors in the water column.

\section{MATERIALS AND METHODS}

Data on the occurrences of red tides were obtained from the Agriculture, Fisheries and Conservation Department (AFCD), Hong Kong Government. 


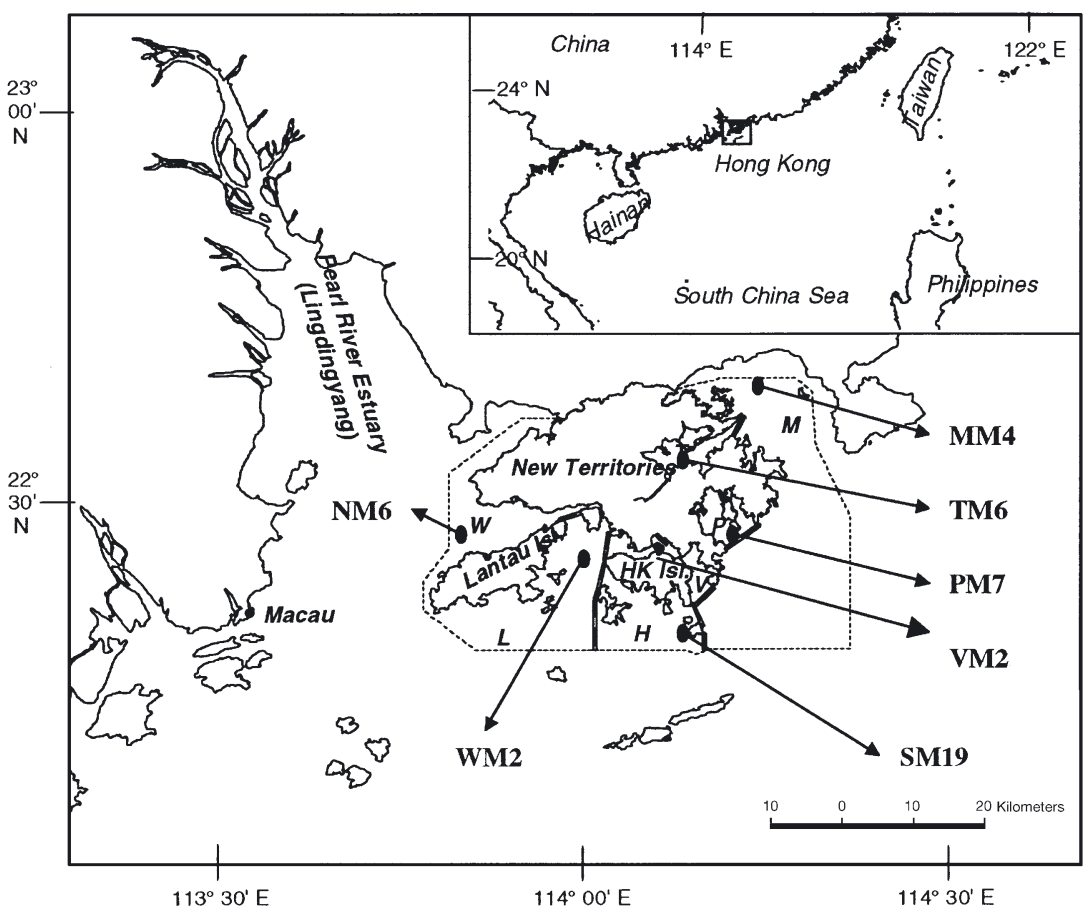

Fig. 1. Stations located near Hong Kong and the Pearl River estuary with the insert showing Hong Kong along the South China coast. The Hong Kong territorial waters are bounded by the dotted line and are divided by thick rail lines into 7 water zones as described in the text. Seven stations at each zone on the map are monitoring stations for water quality data shown in Figs. 9, 10 \& 11. Depths for these stations are: NM3, 13 m; WM2, 14 m; SM19, 12 m; VM2, 12 m; PM7, 15 m; TM6, 12 m; and MM4, $18 \mathrm{~m}$
In a single entry in the database, there were records of more than 1 location or causative species. In these cases, the records were separated into multiple entries by location or species. Therefore, the number of red tides in the GIS database is larger than that in the original records by the AFCD and in the Environmental Protection Department's reports (EPD 1998). If a red tide (1 single species at 1 location) lasted for longer than $1 \mathrm{~d}$, it was counted as 1 entry. The coordinates of the location of red tides were found on the map and added to the database, which were entered into the GIS system (Archview ${ }^{\circledR}$ GIS). Using GIS software, we were able to map all cases of red tides and displayed the monthly spatial distribution of total red tides and the most frequently occurring species.

In this study, the Hong Kong territorial waters (Fig. 1) were divided into 7 water zones (Fig. 2) based on geographic features, which is different from the 10 water control zones defined legislatively by the Hong Kong government. Zone $\mathrm{T}$ includes Tolo Harbour and Tolo Channel; outside zone $\mathrm{T}$ is Zone $\mathrm{M}$, which includes Mirs Bay; $\mathrm{P}$ designates Port Shelter; V designates the
AFCD has a Red Tide Reporting Network among different government agencies and collects data on sightings of red tides using the standardized 'Sighting of Red Tide/Discolored Water Report Form'. The data include locations, dates, the period of the red tide outbreaks and major causative species. As the monitoring program focuses on water discoloration or fish kills in fish farm culture zones and public beaches, the records might have missed red tides that were not visible by color or present in subsurface layers. Some red tide blooms might have been missed and not reported due to their occurrence at sites away from the attention of the public. Note that most of the reported red tides did not cause any harmful effects to fish or humans according to the government reports, and therefore we used the term 'red tides' in this study instead of harmful algal blooms.

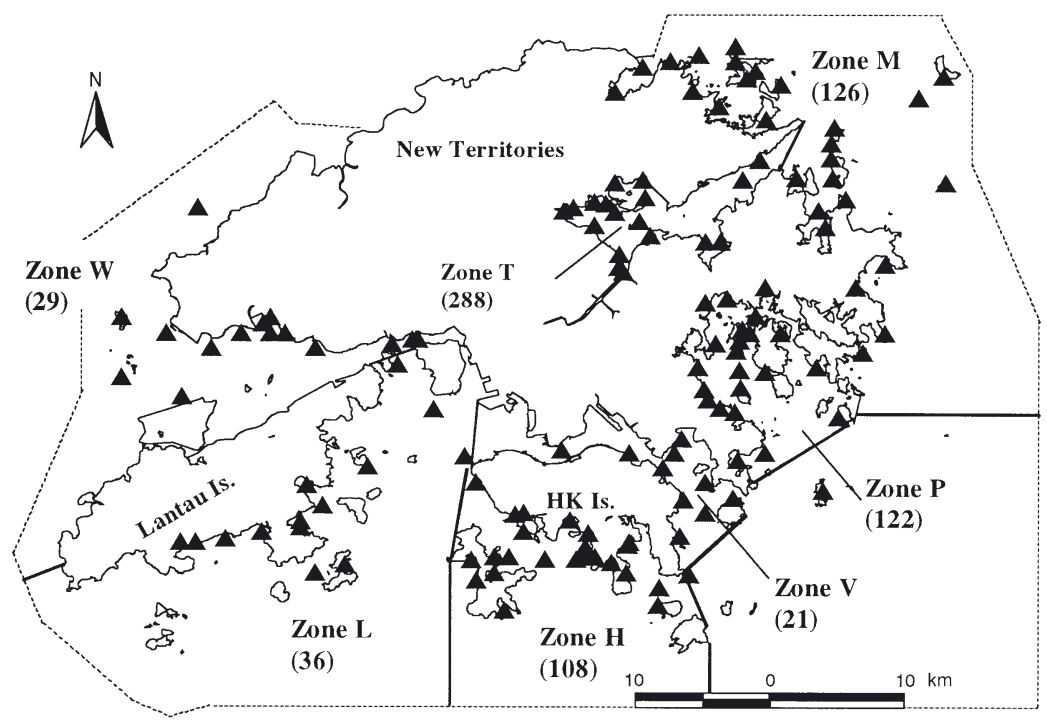

Fig. 2. Spatial distribution of total red tides in Hong Kong during 1983 to 1998. Black solid dots mark the sites of red tide occurrences. Different zones are separated by black lines; they are Tolo Harbor (Zone T), Mirs Bay (Zone M), Port Shelter (Zone P), waters south of Hong Kong Island (Zone H), Victoria Harbor (Zone V), Lamma Channel and south of Lantau Island (Zone L), and the Pearl River estuary and north of Lantau Island (Zone W). The numbers in parentheses underneath each zone are the total number of red tides in the zone 
Victoria Harbour; H is the zone south of Hong Kong Island; L is the zone south of Lantau Island and West Lamma Channel between Lantau and Hong Kong Islands; and $\mathrm{W}$ is the zone between the western New Territories and Lantau Island (Fig. 2).

Data on winds and rainfall were obtained from the Hong Kong Observatory (available at www.hko.gov.hk). For the wind direction and speed, a monthly average was obtained by averaging daily data for the month in a year, which is actually a monthly daily average, and then the monthly averages were averaged over 10 yr from 1991 to 2000. For rainfall, daily values were added for 1 mo for a single year to obtain a monthly average, and the monthly averages were averaged for $10 \mathrm{yr}$ from 1991 to 2000. For the Pearl River discharge, the data from Tables 5 to 19 in Zhao (1990) were used.

Data on salinity, temperature, chlorophyll a (chl a), nitrate $\left(\mathrm{NO}_{3}\right)$, phosphate $\left(\mathrm{PO}_{4}\right)$ and silicate $\left(\mathrm{SiO}_{4}\right)$ were obtained from the marine water quality monitoring program of the EPD. Data used in this study were

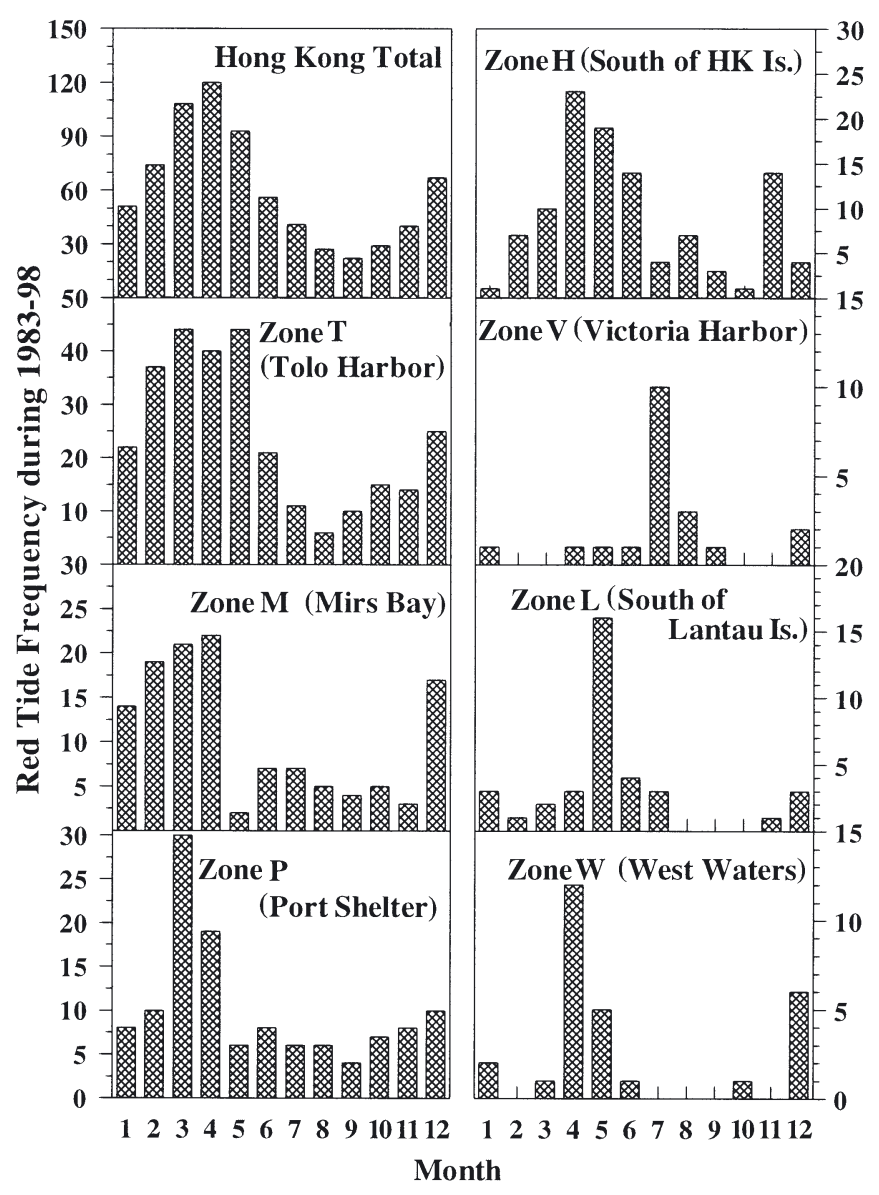

Fig. 3. Monthly distribution of total number of red tides including Noctiluca scintillans in Hong Kong and in 7 water zones (see Fig. 2. for details) of Hong Kong during 1983 to 1998 collected between 1991 and 2000, with bi-weekly, monthly or bi-monthly sampling frequencies, depending on stations. Seven stations (Fig. 1) were chosen to represent water quality in the 7 zones. Data for the surface and bottom were collected $1 \mathrm{~m}$ below the surface and $1 \mathrm{~m}$ above the sediment bottom, respectively. A monthly average of data was obtained by averaging data for that month over $10 \mathrm{yr}$.

\section{RESULTS}

\section{Spatial and temporal distribution}

There were a total of 740 red tides during the period from 1983 to 1998 in the entire Hong Kong region. The red tides occurred more frequently in the eastern territorial waters in Zones $\mathrm{T}$ (288), M (126) and $P$ (122). The other zone where red tides frequently occurred was Zone H (108) (Fig. 2). Comparatively few red tides occurred in the waters of Zone $\mathrm{W}$ in the Pearl River estuary (29) and Zone L (36). The majority of red tides $(70 \%)$ occurred between winter and spring (December to May) (Fig. 3). The frequency of red tides was 51 in January, which increased during February to 75 and then in March to 109 and peaked in April (124). The number of red tides was still high during May (93), but decreased in June (56). The lowest number of occurrences was recorded in September (24) (Fig. 3).

The occurrence of red tides also showed strong seasonal changes. The monthly frequency of red tides in Zones $\mathrm{T}$ and $\mathrm{M}$ in the northeast waters increased from winter to spring, while in Zone $\mathrm{P}$, the occurrences of red tides more than doubled during March and April (Fig. 3) relative to other months during which the number of red tides remained relatively constant (ca. 7 cases). In Zone $\mathrm{H}$, the frequency increased from winter to spring, reaching a maximum (23) during April and then remained high in May and June. Red tides occurred much less frequently in Zone $\mathrm{H}$ during July to October. The exceptionally high frequency (14) in November was due to 1998 alone, which counted for 9 cases. In Zones $\mathrm{W}$ and $\mathrm{L}$, the frequency of red tides showed a single peak in April (12) and May (16), respectively. Most red tides in Victoria Harbor (V) occurred in July (Fig. 3).

\section{Distribution of dinoflagellates and diatoms}

Red tide causative species in Hong Kong were diverse. The most frequently occurring 10 red tide species were, in descending order, Noctiluca scintillans (heterotrophic dinoflagellate), Gonyaulax polygramma 


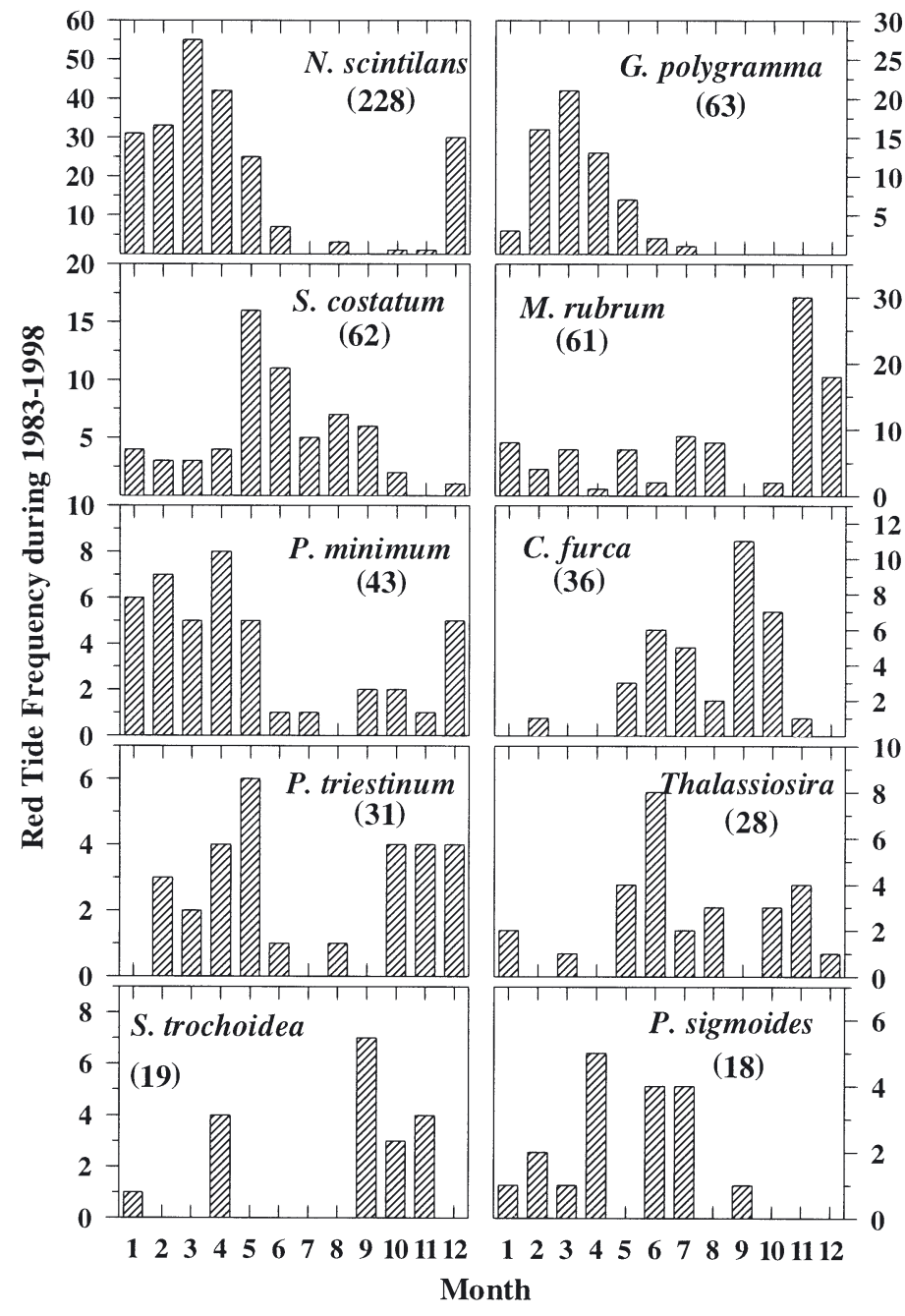

Fig. 4. Monthly distribution and total red tide numbers of the most frequently occurring 10 red tide species in Hong Kong during 1983 to 1998. These species are (in order from highest frequency) Noctiluca scintillans, Gonyaulax polygramma, Skeletonema costatum, Mesodinium rubrum, Prorocentrum minimum, Ceratium furca, P. triestinum, Thalassiosira spp., Scrippsiella trochoidea and P. sigmoides

(dinoflagellate), Skeletonema costatum, (diatom), Mesodinium rubrum (cryptophyte), Prorocentrum minimum (dinoflagellate), Ceratium furca (dinoflagellate), P. triestinum (dinoflagellate), Thalassiosira spp. (diatom), Scrippsiella trochoidea (dinoflagellate), and P. sigmoides (dinoflagellate) (Fig. 4). Nearly all N. scintillans red tides occurred during the period from December to May with the highest frequency during March and were almost absent during July to October (Fig. 4), but its occurrences were widespread (Fig. 5). G. polygramma blooms (53 cases) occurred during February to June (Fig. 4), mostly in the northeastern waters (Zones T, M and P) (Fig. 5). P. minimum and P. triestinum bloomed predominantly during winter and spring (Fig. 4), mostly in the northern zones ( $\mathrm{T}$ and $\mathrm{M}$ ) (Fig. 5), while the other dinoflagellate, C. furca, bloomed mainly in June to October, only in Zones T, M and P (Figs. 4 \& 5). In general, dinoflagellates (including $N$. scintillans) and diatoms appeared to have different spatial and temporal distributions. Dinoflagellate blooms occurred mostly in Zones T, M and P during winter and spring, with the highest frequency in April (Fig. 6). In contrast, blooms of diatoms predominantly occurred during summer (June to July) (Fig. 6). Except for Zone $\mathrm{T}$, diatom blooms occurred more frequently in Zone H (21) than in Zones M (7) and P (11) (data not shown). For example, S. costatum blooms peaked during May and frequently occurred during June to September in Zones T, H and V (Figs. 4 \& 5).

\section{Environmental conditions}

Monsoon winds

Northeasterly to easterly winds blow in winter and southerly to southwesterly winds in summer (Fig. 7A). In fact, the wind direction is not evenly distributed
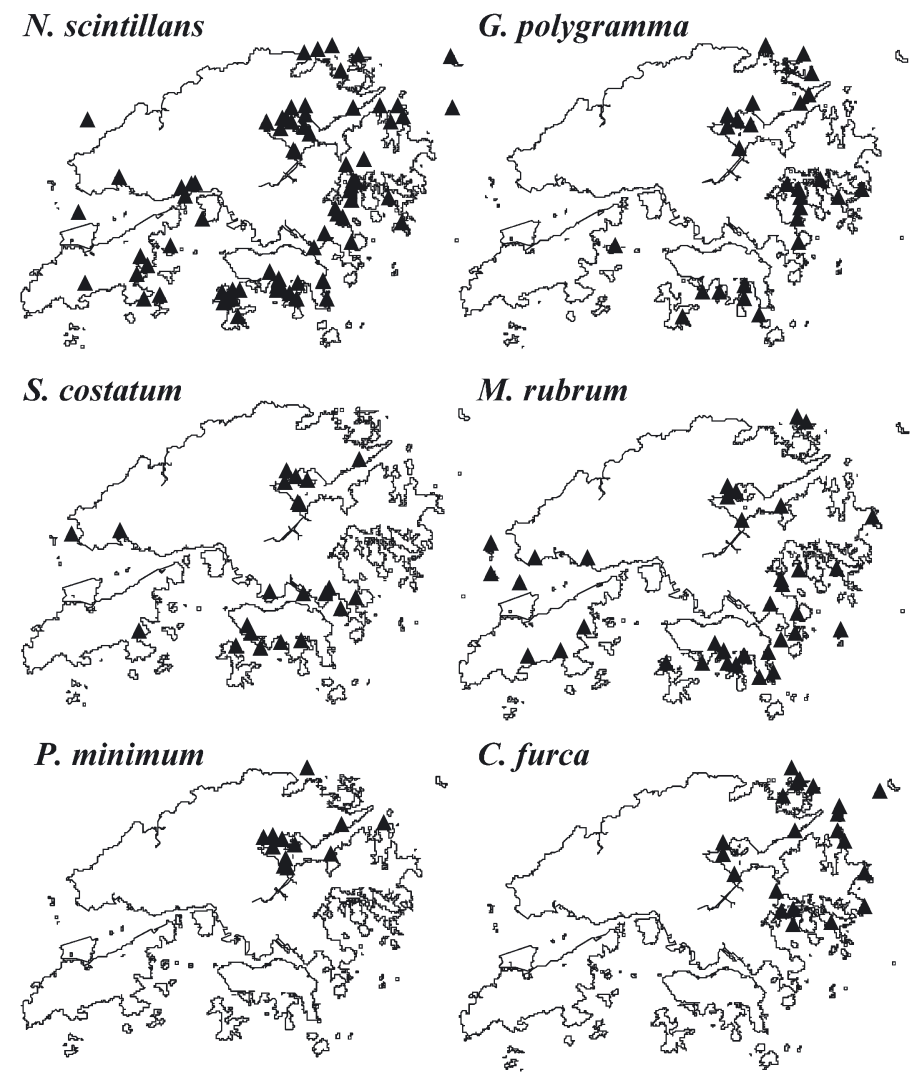

Fig. 5. Spatial distribution of the most frequently occurring 6 red tide species (the same as in Fig. 4) in Hong Kong during 1983 to 1998 

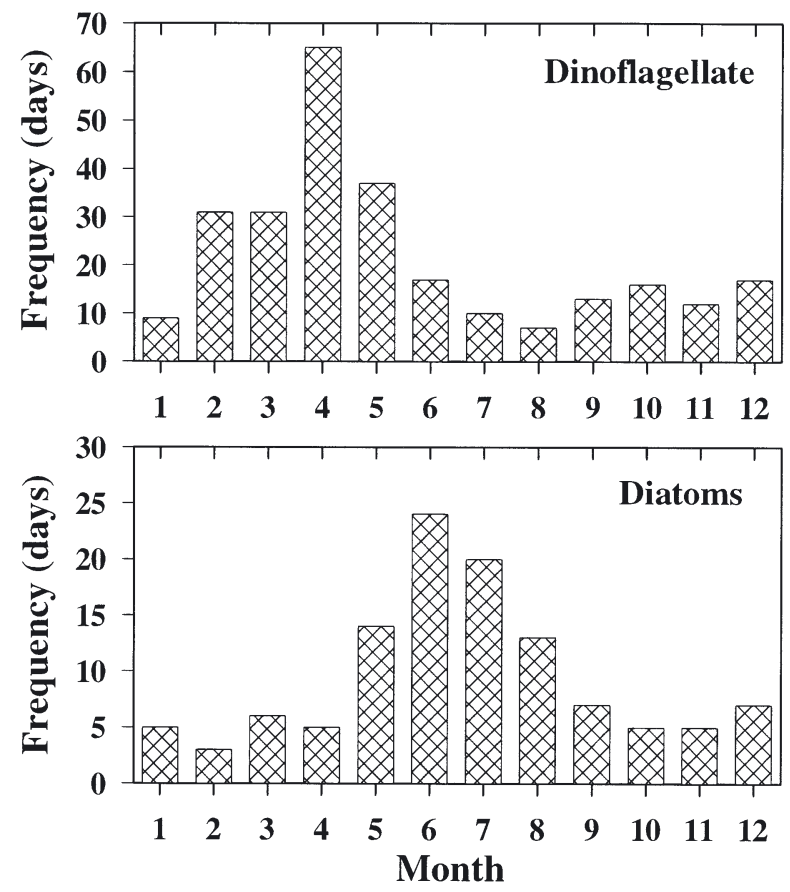

Fig. 6. Monthly distribution of total number of red tides of dinoflagellates including Noctiluca scintillans and diatoms in Hong Kong during 1983 to 1998

over the year, with easterly winds prevailing most of the year (Fig. 7B). Westerly and northwesterly winds are rare events (Fig. 7B). Winds are stronger in the easterly and northerly directions than in other directions (data not shown). Wind speeds range mostly from 4 to $10 \mathrm{~m} \mathrm{~s}^{-1}$ (Fig. $7 \mathrm{C}$ ).

\section{River discharge and rainfall}

The annual average freshwater flow from the Pearl River is $10524 \mathrm{~m}^{3} \mathrm{~s}^{-1}$, with $20 \%$ occurring during the dry season in October to March and $80 \%$ during the wet season in April to September (Fig. 8). The rainy season is during spring and summer. The amount of rainfall follows the river discharge. Mean annual rainfall during 1990 to 1998 was $2480 \mathrm{~mm}$, with $2110 \mathrm{~mm}$ (85\%) falling during April to September (Fig. 8), and the maximal rainfall is in June, July and August.

\section{Salinity and temperature}

Hong Kong waters go through seasonal changes in water masses, circulation and stratification. Each of the 7 zones is influenced by different environmental conditions. Surface salinity decreases to a minimum during July in all 7 zones (Fig. 9), but the minimum salinity increases from west (NM3) to east (MM4 and TM6). Surface temperature increases to a maximum in June and remains high through July and August as well as September (Fig. 9). Bottom salinity increases to a maximum in July at all stations except for NM3. The increase in bottom salinity at each station corresponds to a decrease in surface salinity in July (TM6, MM4 and PM7) and coastal waters (SM19, VM2 and WM2) (Fig. 9). A decrease in bottom temperature in July occurs at these stations as bottom salinity increases (Fig. 9). Haline stratification (defined as a difference in salinity $>1.0$ between the surface and bottom) starts in March at NM3 in the estuary, 1 mo later in April at TM6, MM4, PM6 in the northeast, SM19 and WM2, but even later in June at VM2 in Victoria Harbor. Thermal stratification (defined as a difference in temperature $>1^{\circ} \mathrm{C}$ between surface and bottom) starts 2 mo later than haline stratification in May at NM3 and in June at
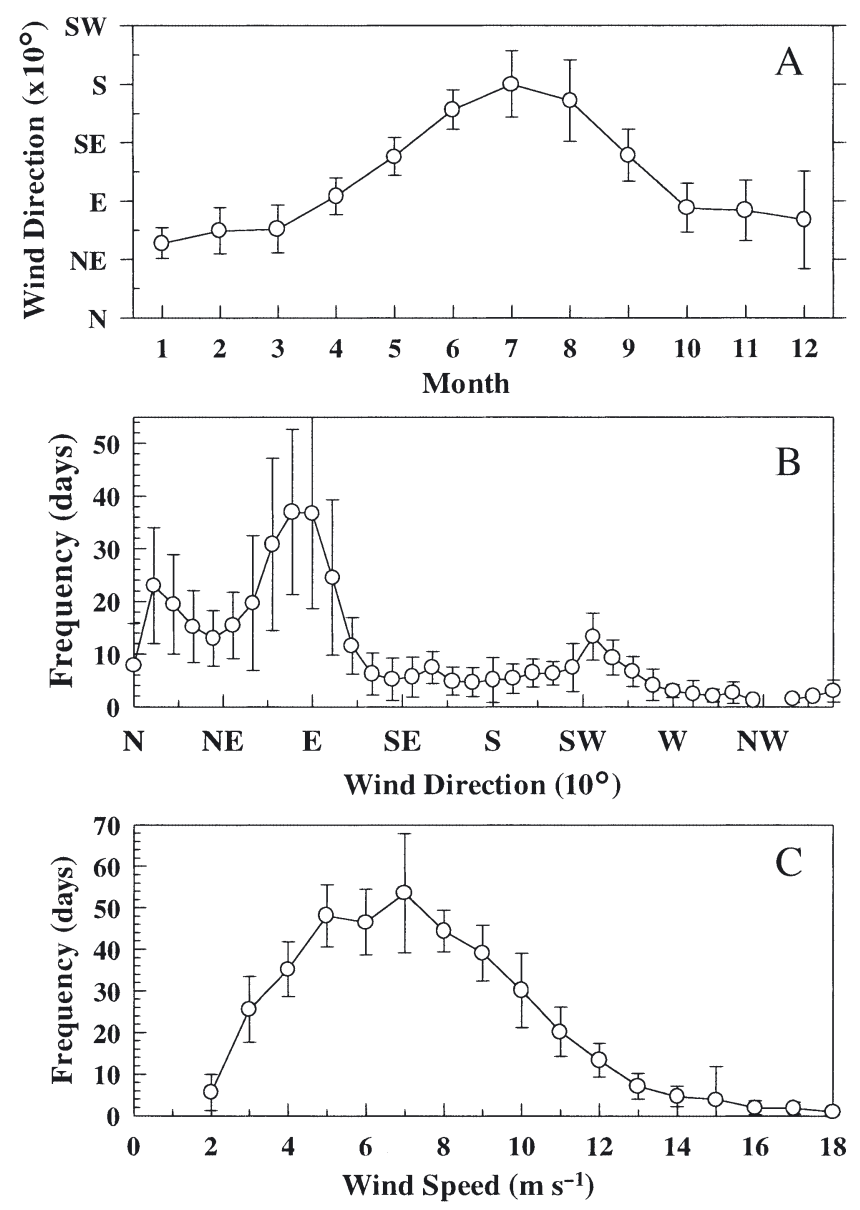

Fig. 7. (A) Monthly distribution of wind directions in Hong Kong, (B) frequency of the occurrence of wind directions and (C) frequency of the wind speed during 1983 to 1998. Vertical bars represent $\mathrm{SD}$ 


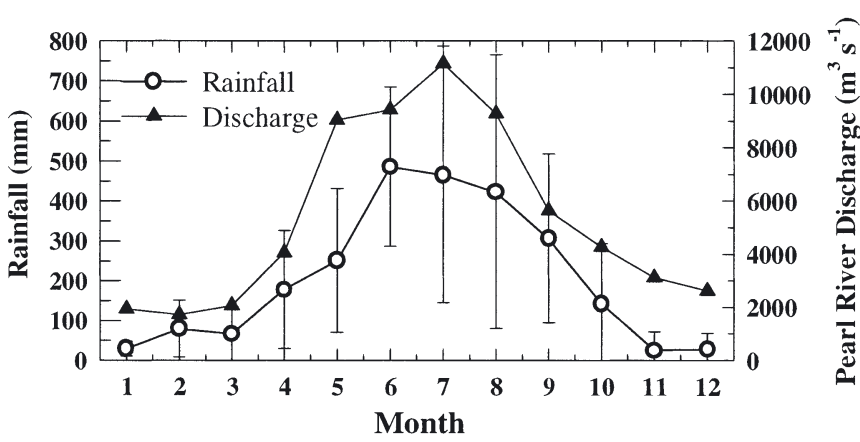

Fig. 8. Monthly mean Pearl River discharge (calculated from Zhao 1990) and rainfall. Vertical bars represent SD

WM2, but earlier in March at TM6 and MM4, in the same month in April at PM7 and SM19, and in June at VM2 (Fig. 9).

\section{Chlorophyll a}

Chl a concentrations are low at NM3, WM2, VM2 and SM19 in winter and spring, and increase to a maximum during July (Fig. 10). The maximum chl a concentration is usually $<10 \mu \mathrm{g} \mathrm{l}^{-1}$ at NM3 and WM2, and $<20 \mathrm{\mu g} \mathrm{l}^{-1}$ at VM2 and SM19, while at PM7 and MM4, chl a concentrations remain below $3 \mu \mathrm{g} \mathrm{l^{-1 }}$ throughout the year except for April. Chl a concentrations at TM6 are the highest among all the stations, remaining near $10 \mu \mathrm{g} \mathrm{l}^{-1}$ all year round with a peak in May (Fig. 10).

\section{Nutrient concentrations}

Surface dissolved inorganic nitrogen (DIN) concentrations at NM3 are $<20 \mu \mathrm{M}$ in winter, start to increase in March, reach a maximum of $70 \mu \mathrm{M}$ in July, and decrease afterwards, back to the winter value in October (Fig. 10). Surface DIN concentrations at WM2 and SM19 follow the similar temporal change as at NM3, but the maximum concentration in July is only $30 \mu \mathrm{M}$ at WM2 and SM19 (Fig. 10). The maximum in DIN coincides with the peak of chl $a$ at these 2 stations. DIN concentrations at PM7, MM4 and TM6 are $<15 \mu \mathrm{M}$ all year. However, surface DIN remains above $20 \mu \mathrm{M}$ at VM2 (Fig. 10), which is due to the contribution of $\mathrm{NH}_{4}$ from the input of sewage effluent. $\mathrm{PO}_{4}$ concentrations do not show strong seasonal variations, but are usually $<1 \mu \mathrm{M}$ at all stations except for VM2 (Fig. 11). $\mathrm{SiO}_{4}$ concentrations (Fig. 11) almost follow seasonal changes in DIN concentrations, being low in winter and high in summer at estuarine-influenced stations at NM3, WM2 and SM19. $\mathrm{SiO}_{4}$ concentrations are low $(<5 \mu \mathrm{M})$ at MM4 and PM7, particularly during April to June (Fig. 11).

\section{DISCUSSION}

Physical processes such as winds and river outflow are driving forces to coastal water circulation, mixing and residence time in estuaries, semi-enclosed bays and coastal waters, and therefore influence the dynamics of algal blooms in different zones. Red tides in Hong Kong waters, in a subtropical setting, display special features which are different from ones in temperate regions. For example, the high season for red tides is during late winter to late spring in Hong Kong compared to the high season for red tides during summer in temperate regions; red tides are usually localized in shallow areas of semi-enclosed bays and rarely occur in open waters; while in temperate waters, red tides can be large-scale events, as reported for the East China Sea and confirmed by satellite images (unpubl. data). Hot spots of red tides occur in the northeastern
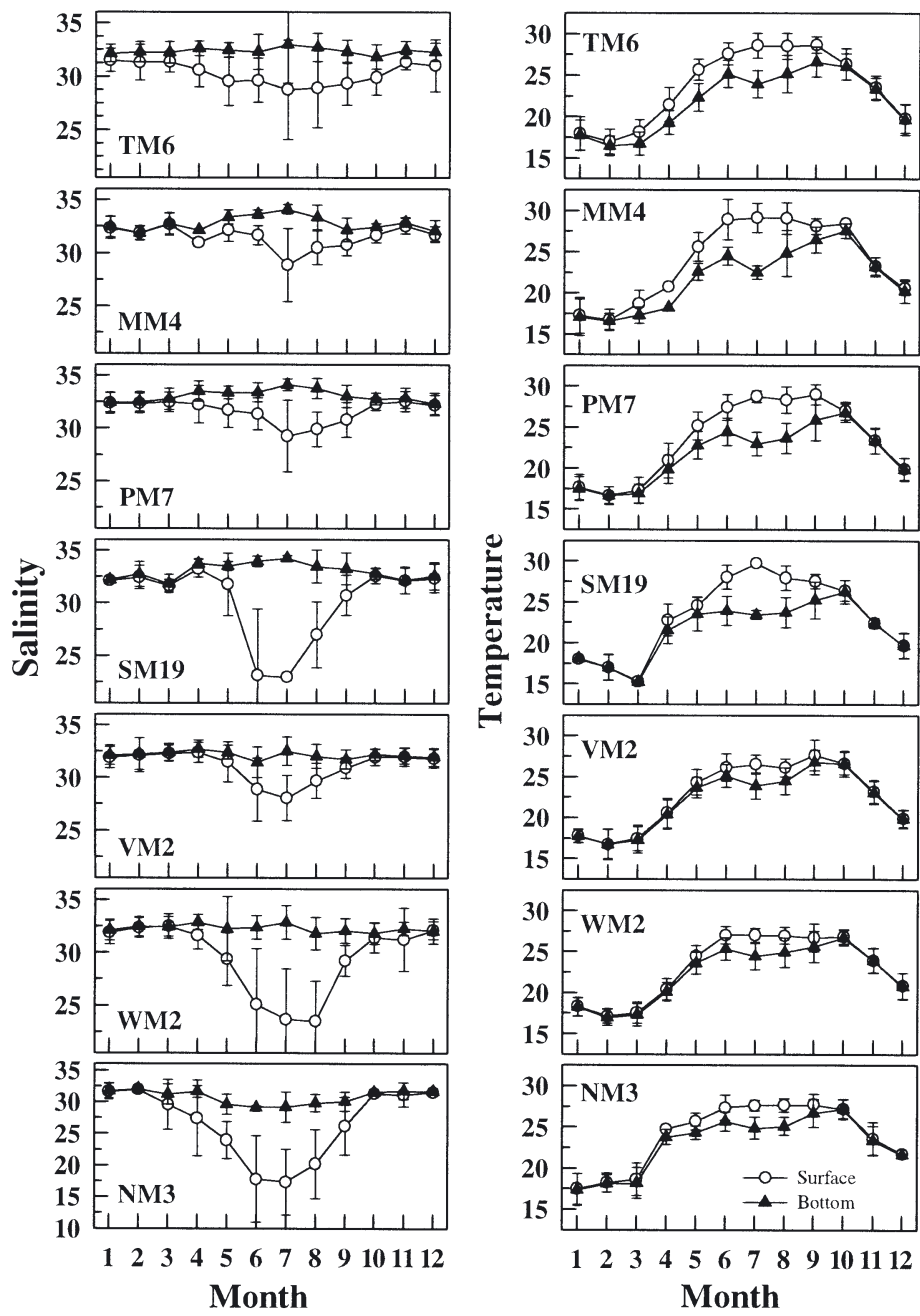

Fig. 9. Monthly average of salinity and temperature during 1991 to 2000 at the 7 stations (EPD monitoring data), representing the 7 zones. Vertical bars represent SD 

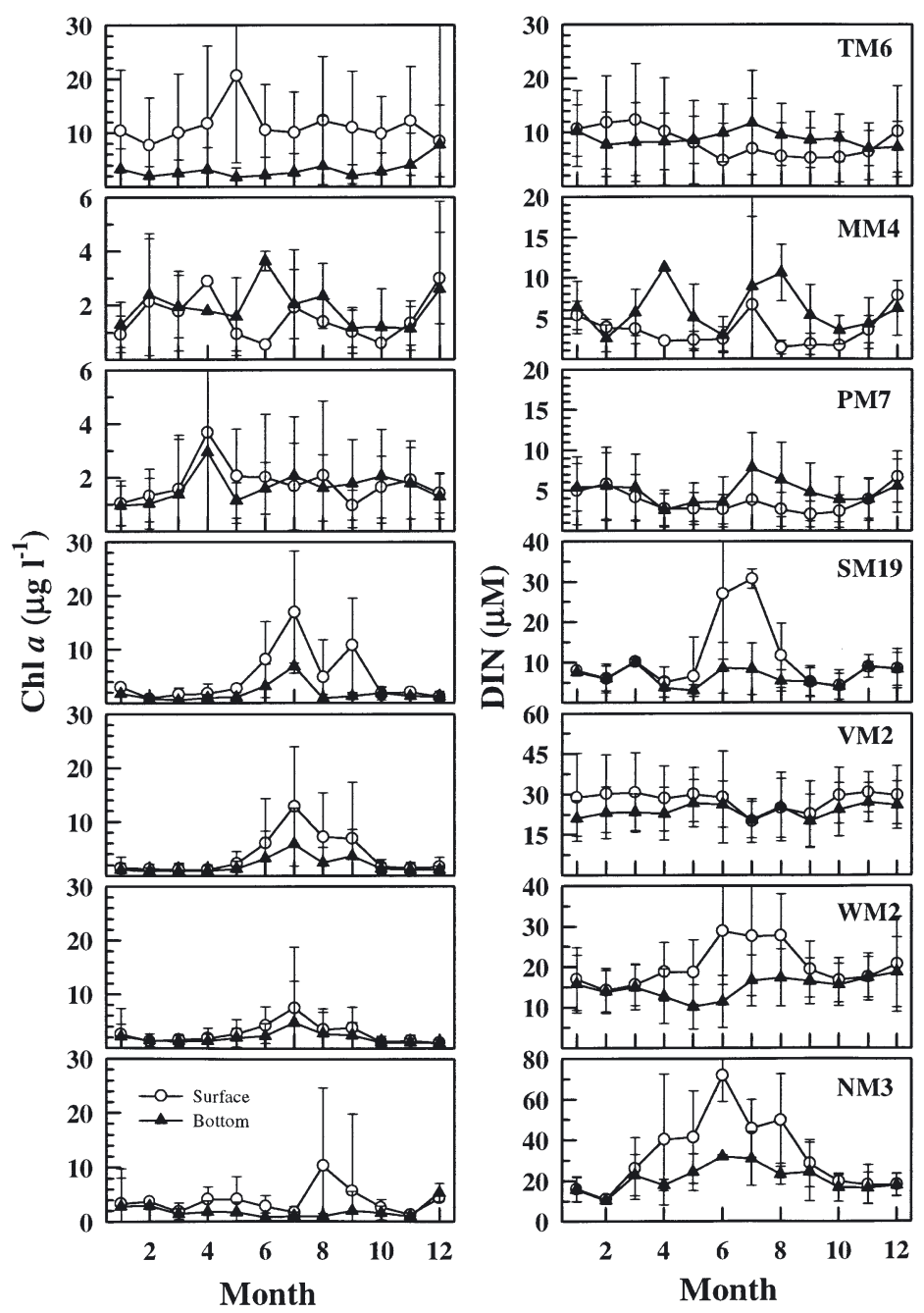

Fig. 10. Monthly average of chl a and DIN $\left(\mathrm{NO}_{3}+\mathrm{NO}_{2}+\mathrm{NH}_{4}\right)$ during 1991 to 2000 at the 7 stations (EPD monitoring data).Vertical bars represent SD

waters of Hong Kong away from the strong influence of the Pearl River estuary, which is contrary to expectation: red tides should occur more frequently in the more eutrophified estuary or estuarine-influenced waters. It appears that red tides are related to regional oceanographic conditions and processes in different zones influenced by monsoons and the Pearl River discharge.

The euphotic zone of the water column in a natural body can be considered to be in the 3 culture modes: a batch culture, semi-continuous culture or continuous culture, depending on dilution or residence times by horizontal exchange and vertical mixing. Basically, physical processes set the modes for phytoplankton to develop blooms either by direct nutrient enrichment or by other mechanisms. In the case of nutrient enrichment, the limiting nutrient in the euphotic zone or in the surrounding waters, e.g. outside the bay or the bottom layer, will determine the ultimate phytoplankton biomass. If phytoplankton biomass exceeds the amount that a nutrient can support at a particular time, then a concentrating mechanism must operate at that time.

\section{Monsoonal influence}

Prevailing winds causing downwelling due to the Coriolis effect are important in regulating algal blooms in coastal waters. In coastal embayment or semienclosed bays along the coast, downwelling results in the movement of surface coastal waters shoreward against the bottom water. As a result, the water exchange between semi-enclosed bays and open waters is reduced, and hence the residence time of the water in the bay becomes longer during downwelling. The water bodies in these semi-enclosed waters could be considered to be analogous to a batch culture which allows sufficient time for phytoplankton to respond to local nutrient inputs and may allow vertical migration of flagellates to play a role in the formation of HABs. Thus, HABs have been reported to be associated with the relaxation of upwelling or the subsequent downwelling (Pitcher et al. 1993). For example, HABs of dinoflagellates such as Alexandrium catenella and Dinophysis spp. in the Saldanha Bay located in the southern Benguela system on the west coast of South Africa were reported to occur when the bottom water flows outwards due to the relaxation of upwelling on the continental shelf (Probyn et al. 2000), because this increased the stratification of the bay and hence the residence time (Monteiro \& Largier 1999). Other cases relating HABs to downwelling have been reported for blooms of Gyrodinium aureolum in Norwegian waters (Dahl \& Tangen 1993), and for the dominance of 2 chain-forming dinoflagellates, Gymnodinium catenatum and Protogonyaulax affinis, in the Ria de Vigo, a coastal embayment in northwest Spain (Fraga et al. 1988, Fraga \& Bakun 1993, Gomez et al. 1996). HABs related to the longer residence times of various bays included the formation of Chattonella red tides in Harima Nada, Japan, even though the vertical stability was low (Iwata et al. 1989), the brown tide, Aureococcus anophagefferens, in Great South Bay and other embayments on Long Island, New York, during the spring of 1985 (Nixon et al. 1994), and Ceratium furca blooms in 1987 in St. Helena Bay (Walker \& Pitcher 1992).

In Hong Kong, seasonal monsoons result in the downwelling of coastal waters of the South China coast during winter and spring during northeast-east winds and upwelling during late spring and summer 

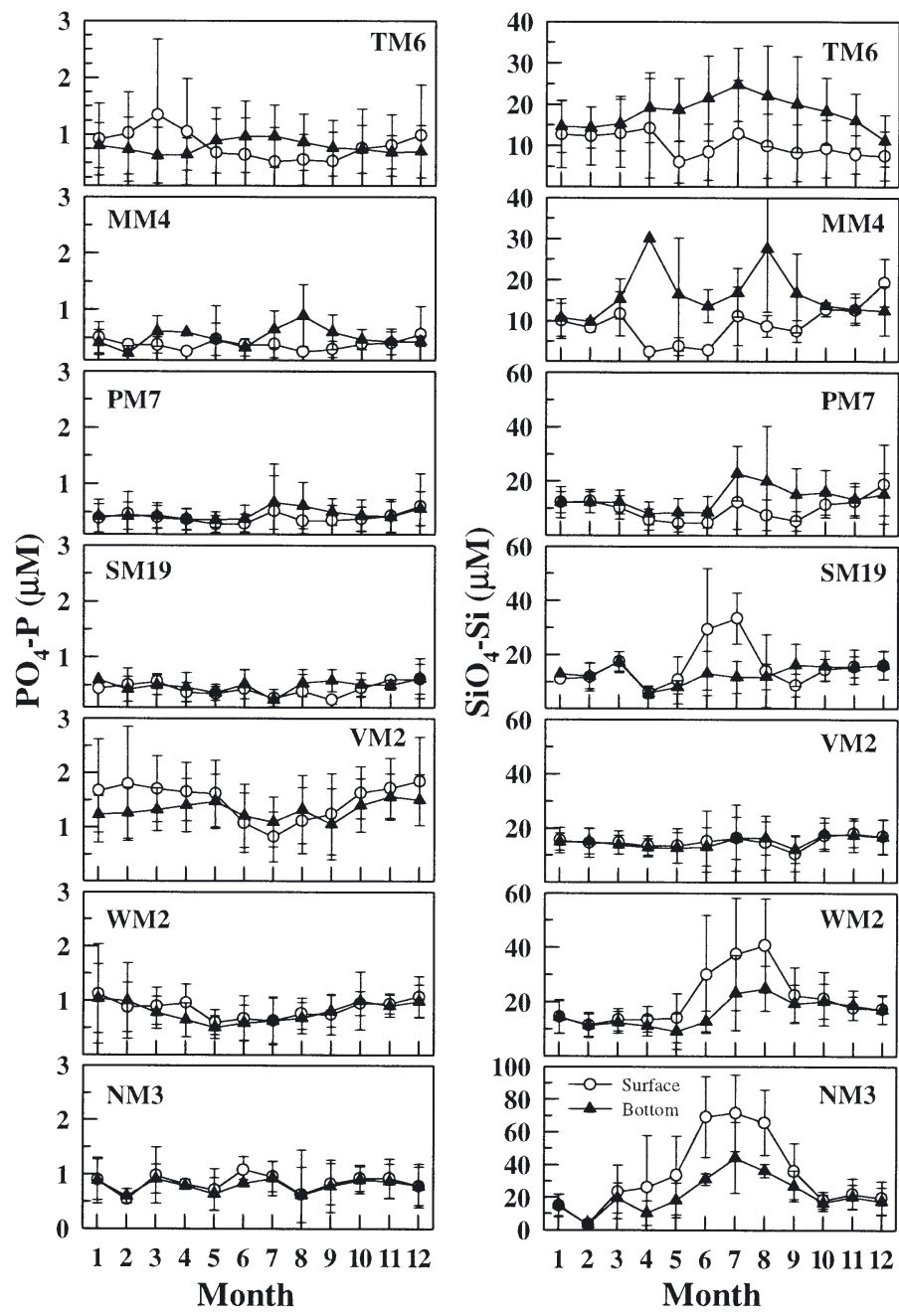

Fig. 11. Monthly average of $\mathrm{PO}_{4}$ and $\mathrm{SiO}_{4}$ during 1991 to 2000 at the 7 stations (EPD monitoring data). Vertical bars represent $\mathrm{SD}$

during southwest winds. As a result, during December to April, the China Coastal Current that originates from the north, dominates the Hong Kong coastal water circulation (Chau \& Wong 1960, Williamson 1970, Watts 1971, 1973, Yin et al. 1999). Mirs Bay (Zone M) and Port Shelter (Zone P) are semi-enclosed, and Tolo Harbor and Channel (Zone T) are sheltered within Mirs Bay (Fig. 1). High salinity (above 30) at the surface during December to April in these waters (Stns TM2, MM4 and PM7) indicates the invasion of coastal water during this downwelling period. Stratification in these zones during winter is weak, but the sites of red tides were all shallow $(<10 \mathrm{~m})$, possibly within the euphotic zone. Starting in April/May, the wind direction shifts from the northeast monsoon to the southwest monsoon, which causes a decrease in the exchange with offshore water. In addition, water depths are $<20 \mathrm{~m}$ in most areas of these bays and shallower $(<15 \mathrm{~m})$ in the waters where red tides mostly occur, and the euphotic zone can be relatively deep due to the dominance of clear coastal waters, and the $1 \%$ light depth is down to $20 \mathrm{~m}$, for example, in Port Shelter (author's unpubl. data). Thus, the downwelling, increased residence time of the water and the relatively high transparency create conditions analogous to a batch culture for these waters. Most red tides in these 3 zones ( $\mathrm{T}, \mathrm{M}$ and $\mathrm{P}$ ) northeast of Hong Kong occur during winds in the northeast and east directions (Fig. 12). In contrast, red tides occur much less frequently during the southwest wind and other wind directions (Fig. 12) in these 3 zones (T, M and $\mathrm{P})$. The frequency of red tides versus wind direction in Fig. 12 resembles the frequency of days versus wind direction in Fig. 7b. The statistical analysis between 2 frequencies yielded significant correlation for all zones, Tolo Harbor and Mirs Bay (Fig. 13),

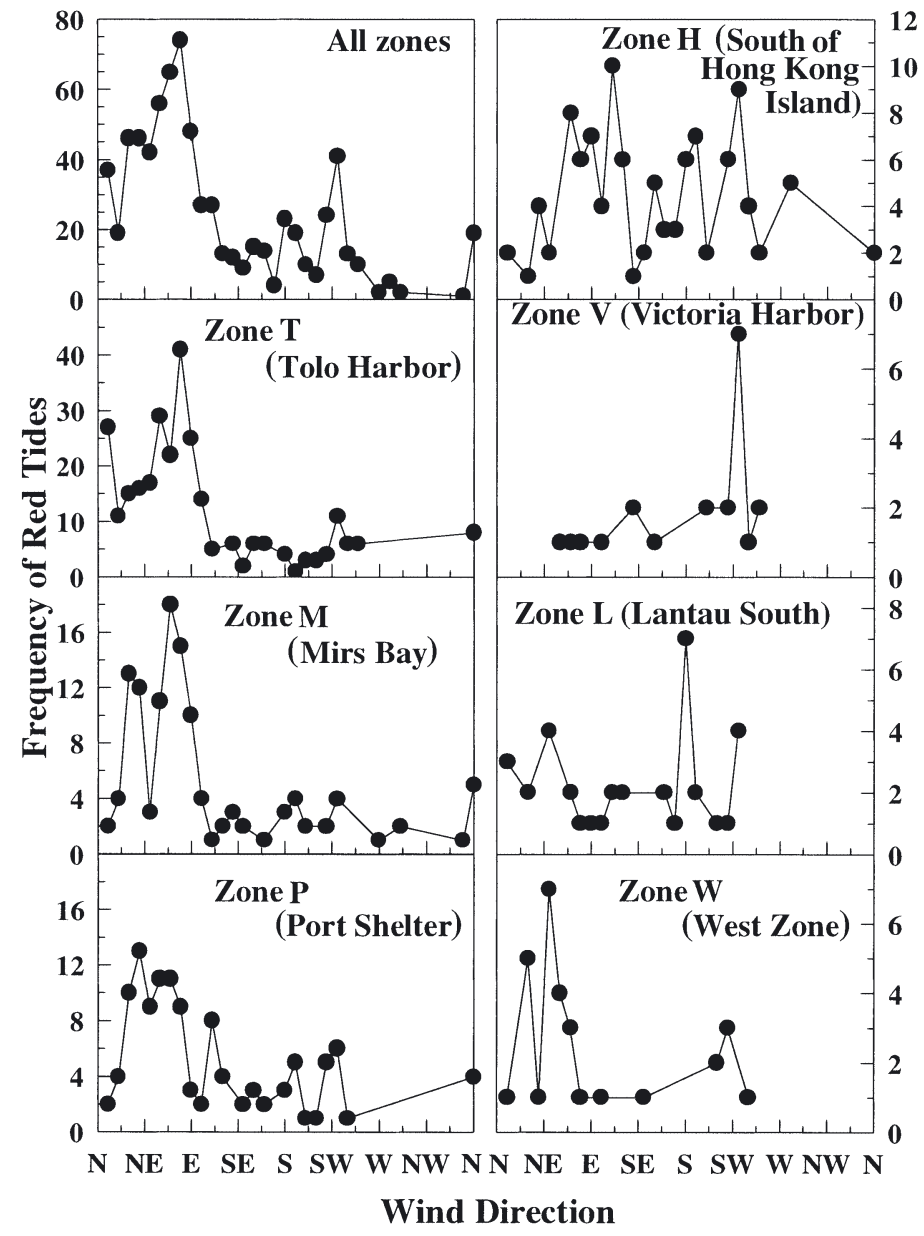

Fig. 12. Frequency of total number of red tides including Noctiluca scintillans during 1983 to 1998 versus wind directions during the same times of occurrences of red tides 


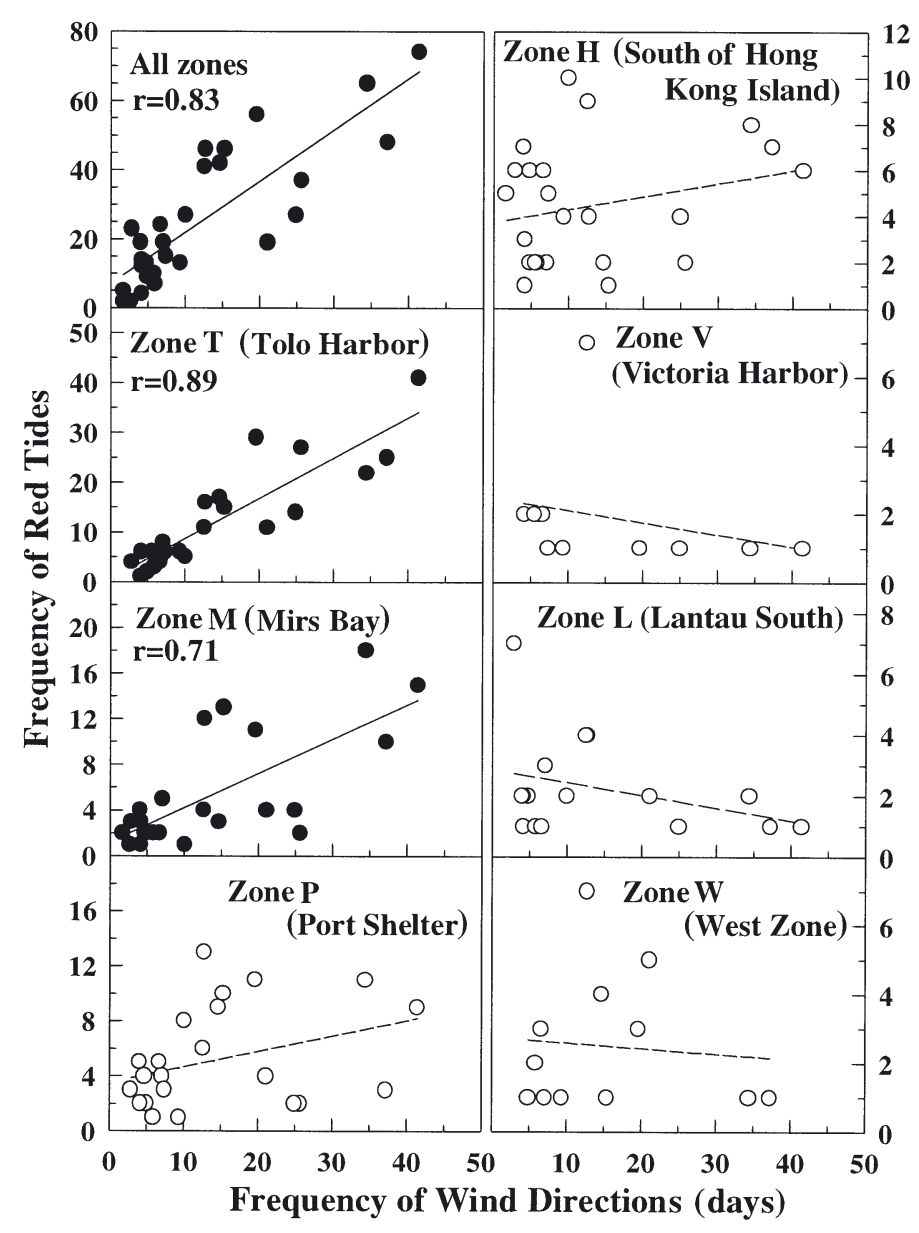

Fig. 13. Frequency of total number of red tides including Noctiluca scintillans under different wind directions. The $y$-xis in Fig. 12 is plotted against the $y$-axis in Fig. 7B, yearly average frequency of wind directions during the same period (1983 to 1998). The solid lines represent significant correlations at $\mathrm{p}<0.05$ and the dashed lines are not significant

although no significant correlations for other zones. The significant correlation suggests that variation of wind directions explained $83 \%$ of red tides for all zones in Hong Kong, 89\% for Tolo Harbor and 71\% for Mirs Bay (Fig. 13).

\section{Estuarine processes and conditions}

In summer, the southwest monsoon is the source of prevailing winds that drive upwelling along the coast. The Pearl River discharge and maximal rainfall in summer causes the estuarine circulation (freshwater outflow at the surface and salt water inflow at the bottom) in the Pearl River estuary and in semienclosed bays, and the estuarine coastal plume strengthens upwelling circulation in coastal waters.
Therefore, residence times during summer are reduced in semi-enclosed waters and coastal waters of Hong Kong. Red tides occur less frequently in the Pearl River estuary (Zone W) than other zones of Hong Kong. These waters have estuarine characteristics such as variable salinity, high turbidity and high turbulence, due to interactions of river outflow, tidal flow and winds, which are particularly dominant during the months of high river discharge in July. These environmental conditions are not suitable for dinoflagellates, some of which cannot tolerate high concentrations of suspended particles (Shirota 1989) and turbulence. In spite of high nutrient concentrations in the Pearl River estuary (Figs. 10 \& 11), relatively few blooms occur in this area, and none occur during July to September. The exception is Noctiluca scintillans, which can tolerate turbulent water (Elbrachter \& Qi 1998). Similar estuarine conditions are present in Zone L during the season of high river discharge, and hence the number of red tides in Zone L is close to that in Zone W. However, as Zone L is a relatively open area, south winds push the surface water against the shore. Therefore, red tides occur more frequently during southern winds in Zone L and more frequently during northeast winds in Zone W (Fig. 12).

\section{Nutrients}

Eutrophication has been regarded as a major cause in the wide spread occurrence of HABs (NRC 2000). However, in many cases, red tides are not necessarily a direct result of nutrient enrichment when one compares the biomass of the phytoplankton in a red tide with how much biomass the ambient concentration of a nutrient can produce. Based on the mass balance between concentrations of an inorganic nutrient and particulate organic matter of that nutri-

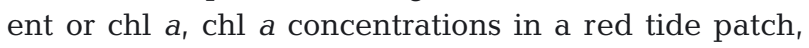
which are usually very high and comparable to a laboratory culture where the color is visible, cannot be supported by ambient nutrient concentrations. For one of the red tides observed in Port Shelter, the concentration of chl a was $68 \mu^{-1} \mathrm{l}^{-1}$ (author's unpubl. data). Chl a values of the red tide patches are reported to be between 125 and $500 \mu \mathrm{g} \mathrm{l}^{-1}$ in the Guayas River and in the inner estuary of the Gulf of Guayaquil (Jimenez 1993). Normally, peak concentrations in chl a during April in Mirs Bay and Port Shelter (Stns MM4 and PM7, respectively; Fig. 10) are $<10 \mu \mathrm{g} \mathrm{l}^{-1}$ and are $<25 \mu \mathrm{g} \mathrm{l}^{-1}$ during June to July in the southern waters of Hong Kong (SM19) and other zones, respectively (Fig. 10). Only in Tolo Harbor, do peak concentrations of chl a frequently reach $30 \mathrm{\mu g} \mathrm{l}^{-1}$. Inorganic nitrogen concentrations are low 
$(<10 \mu \mathrm{M})$ in Mirs Bay and Port Shelter (Stns MM4 and PM7, respectively; Fig. 10) and not high enough to support high phytoplankton biomass, certainly not to the level of chl a measured in a red tide. In other zones (Stns SM19, WM2, and NM3; Fig. 10), $\mathrm{NO}_{3}$ concentrations are higher in the west than in the east and increase in summer, indicating the influence of the Pearl River estuarine plume. When chl a increases, $\mathrm{NO}_{3}$ also increases. This indicates that nitrogen is not the controlling nutrient. $\mathrm{PO}_{4}$ concentrations are usually $<1 \mu \mathrm{M}$ in all zones except for Victoria Harbor (Stn VM2; Fig. 11). The concentration of $1 \mu \mathrm{M} \mathrm{PO}_{4}$ can produce a biomass of $16 \mu \mathrm{g} \mathrm{l}^{-1}$ chl a (T. Anderson 1997). The previous studies have shown that phosphorus is the most limiting nutrient in the estuarine-influenced waters (Yin et al. 2000, 2001). The spatial and temporal distribution of chl $a$ and low phosphorus concentrations suggest that there must be concentrating mechanisms of phytoplankton cells for the formation of red tides in Hong Kong waters. Low silicate concentrations at the surface during April to May in Mirs Bay and Port Shelter (Stns MM4 and PM7, respectively; Fig. 11) and in the southern waters of Hong Kong (Stn SM19; Fig. 11) may possibly limit diatom blooms during these periods, and hence allow dinoflagellate blooms to occur during April to May. During summer, higher silicate concentrations due to the estuarine-plume influence or coastal runoff allow diatoms to outgrow dinoflagellates. Many dinoflagellates blooms such as Heterocapsa triquetra, Gymnodinium nelsoni, Gyrodinium spirale, Ceratium minutum, Prorocentrum triestinum, $P$. minimum and $P$. micans were reported to occur between diatoms blooms when silicate was depleted in Buzzards Bay, MA (Borkman et al. 1993). In addition, during summer, oceanic waters, which flow into the bottom of Mirs Bay and Port Shelter, are nutrient-poor, and thus this may reduce the ability of vertically migrating dinoflagellates to acquire nutrients in the bottom layer. Fast flushing and low nutrients at the bottom may explain fewer occurrences of red tides in late spring and summer in spite of stronger stratification.

A big question is: Does nutrient enrichment in coastal waters play any role in leading to an increased number of red tide occurrences? If not, why do occurrences of red tides increase if seasonal physical regimes have not changed very much over the last 2 decades? The answer to the question is yes: nutrient enrichment should play an important role, but not in a direct fashion. For example, when the concentration of inorganic nitrogen was $2 \mu \mathrm{M}$ in the past, this amount of nitrogen can produce about $2 \mu \mathrm{g} \mathrm{chl} \mathrm{a} \mathrm{l}^{-1}$ using a con-

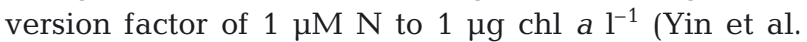
1996). A 10-times aggregation would give $20 \mu \mathrm{g} \mathrm{chl} \mathrm{a}$ $\mathrm{l}^{-1}$, which is not very visible. When the concentration of nitrogen increased from 2 to $6 \mu \mathrm{M}$, a phytoplankton biomass of $6 \mu \mathrm{M} \mathrm{N}$ is still not visible, but the same 10

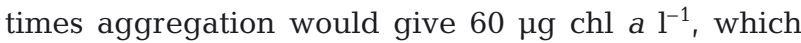
becomes visible. In the eastern waters of Hong Kong, nutrients may have been increasing, although concentrations are still considered to be low. However, this may have increased phytoplankton biomass in the water column by a few times, so that aggregation of the algal biomass can form red tides. Noctiluca scintilans is the main red tide species in northeastern waters. This dinoflagellate is heterotrophic and it consumes other phytoplankton such as diatoms (Nakamura 1998a,b). In addition, it is a very buoyant species, and hence it usually occurs right at the surface with its bright red pigments easily visible from some distance. An increase in phytoplankton biomass due to the increased input of local nutrients would have increased food supply to this species, and this may be responsible for the large number of sightings of this species.

\section{Physical processes and vertical migration}

Frequent red tides in low nutrient waters with low chl $a$ such as in Mirs Bay and Port Shelter appear to suggest concentration mechanisms of phytoplankton during the formation of red tides. However, the concentrating process requires either physical inducing conditions and processes, or vertical migration or swimming aggregation behavior of phytoplankton. There is evidence suggesting the hydrologically induced formation of red tides (Voltolina et al. 1985) along the Skagerrak coast (Lindahl 1993) and in Great South Bay, Rhode Island (Nixon et al. 1994). In St. Helena Bay, the bloom of Ceratium furca appears to represent the accumulation of slow-growing ungrazed populations subject to concentration by physical entrainment and vertical migration (Walker \& Pitcher 1991). The physical process-induced red tides often involve vertical migration of dinoflagellates. Vertical migration gives dinoflagellates the advantage of carrying out photosynthesis in the surface layer during the day (Takahashi \& Hara 1989) and utilizing high nutrients in a deeper layer at night, including nitrogen (Dortch \& Maske 1982, Yamochi 1989) and phosphorus (Watanabe et al. 1988). Therefore, this ability of vertical migration has been reported to contribute to the formation of many species of HABs, including: Gymnodinium catenatum (Alvarez-Salgado et al. 1998); 4 dinoflagellate species (Ceratium furca, Scrippsiella trochoidea, Dinophysis acuminata and Eutreptiella) and Mesodinium rubrum (Villarino et al. 1995); Heterosigma akashiwo (Raphidophyceae) 


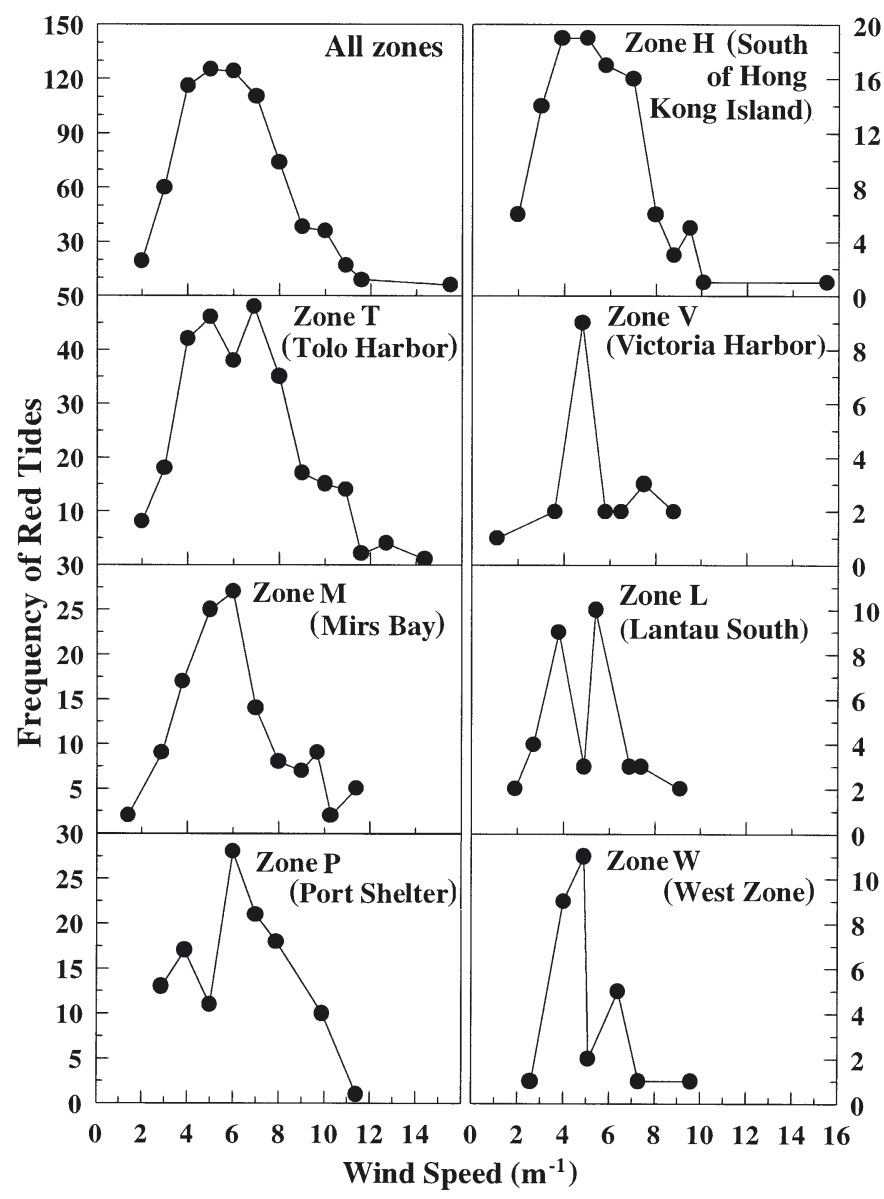

Fig. 14. Frequency of total number of red tides including Noctiluca scintillans during 1983 to 1998 versus wind speeds during the sametimes of occurrences of red tides

(Takahashi \& Hara 1989, Yamochi 1989, Taylor \& Haigh 1993); and Gymnodinium nagasakiense (Honjo et al. 1990).

In Hong Kong, most red tides are localized at small spatial scales. It is likely that vertical migration of dinoflagellates plays an important role in concentration or aggregation of dinoflagellates to form a red tide. A moderate wind speed of 4 to $7 \mathrm{~m} \mathrm{~s}^{-1}$ appears to be the most favorable for red tides (Fig. 14). This range of wind speeds is considered to be high enough to cause vertically homogenous mixing of the water column, e.g. in the Strait of Georgia (Yin et al. 1997) and the St. Gulf of Lawrence (Levasseur et al. 1984). When winds blow at this range of speeds during most of the year in Hong Kong (Fig. 7C), turbulent mixing in open waters can be strong. Therefore, red tides can hardly be formed in open waters of Hong Kong. In semienclosed waters, turbulent mixing would be reduced during winds of moderate speeds. Depending on the wind direction and duration, convergent fronts may be formed, which can induce aggregation of dinoflagellates or even concentrate diatoms. Based on visual observations, many red tides occur in patches parallel to the shoreline (M. Wong pers. comm.). The distribution of frequency of red tides in Fig. 14 versus wind speeds resembles yearly average frequency of wind speeds in Fig. 7C. Statistical analysis produced significant correlation between the 2 frequencies for all zones in Hong Kong, for Tolo Harbour and Mirs Bay (Fig. 15). The significance of correlation suggests that wind speeds are important in the formation of red tides in Hong Kong waters.

In summary, red tides are a visual manifestation of the interplay between oceanography and phytoplankton ecology. Hong Kong waters are situated in a special geographic setting with semi-enclosed bays on the east and the Pearl River estuary on the west. As the prevailing wind directions of monsoons shift with seasons and the Pearl River discharge changes seasonally, the oceanographic conditions and pro-

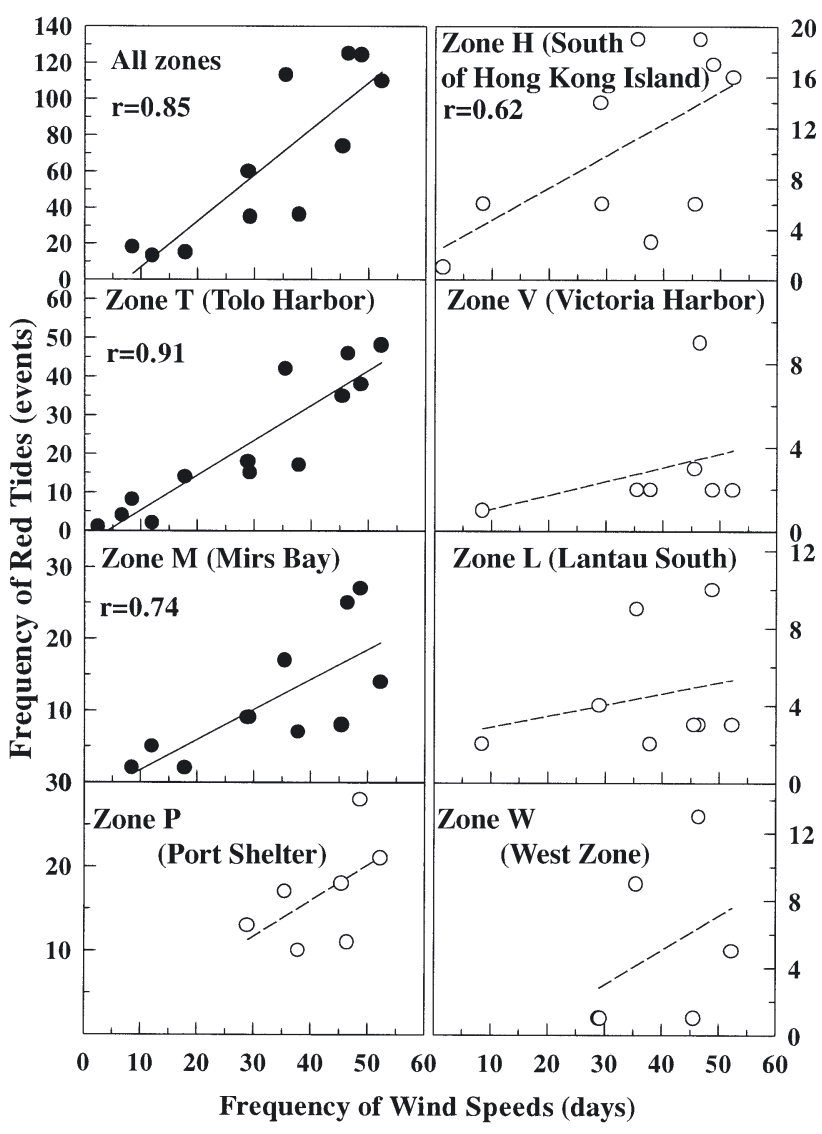

Fig. 15. Frequency of total number of red tides including Noctiluca scintillans under different wind speeds. The $y$-axis in Fig. 14 is plotted against the $y$-axis in Fig. 7C, yearly average frequency of wind speeds during the same period (1983 to 1998). The solid lines represent significant correlations at $p<$ 0.05 and the dashed lines are not significant 
cesses in different zones change with the seasons. Time series of red tides and water quality data in Hong Kong provide us with a unique opportunity to examine how the formation of red tides is related to the interplay between oceanography and phytoplankton ecology. It appears that the northeast monsoon in winter-spring drives downwelling of the coastal water and sets up the semi-enclosed bays in the east of Hong Kong into a batch culture mode in which the response to local inputs of nutrients and vertical migration of phytoplankton or the concentrating mechanisms become dominant driving forces to algal blooms. In summer, the southwest wind and the Pearl River discharge cause upwelling of the coastal water, surface outflow of the semi-enclosed waters and the estuarine circulation in the Pearl River estuary. This sets up these water bodies to function somewhat like a semi-continuous culture. Depending on dilution rates, phytoplankton may accumulate fast enough to form blooms. These 2 seasonal processes are believed to be primarily responsible for more red tides in the semi-enclosed bays in winter to spring than in summer. The flow in the Pearl River estuary is fast as the river discharge reaches the maximum, producing a washout effect. This accounts for few red tides in the estuary. Silicate concentrations are low in these semi-enclosed bays in winter to spring and high in the southern waters in summer. This would also contribute to more occurrences of dinoflagellates red tides in the northeast than in the southwest.

Acknowledgements. I thank the Agriculture, Fisheries and Conservation Department, and the Environmental Protection Department, Hong Kong Government for providing and permitting publication of the records of red tides and environmental monitoring data, respectively. Prof. Paul J. Harrison provided many helpful comments on the manuscript. Michelle Legault provided technical assistance to the GIS operation. This study was supported by the projects ZKCX2-SW-212, 2001CB409703, and 2002A3050103. The author also acknowledges the support from the National Science Foundation of China (40125016) and HK RGC(HKU1)/ 02C-HKUST CA02/SC04.

\section{LITERATURE CITED}

Alvarez-Salgado XA, Figueiras FG, Villarino ML, Pazos Y (1998) Hydrodynamic and chemical conditions during onset of a red-tide assemblage in an estuarine upwelling ecosystem. Mar Biol 130:509-519

Anderson DM (1997) Bloom dynamics of toxic Alexandrium species in the northeastern U.S. Limnol Oceanogr 42: 1009-1022

Anderson T (1997) Pelagic nutrient cycles: herbivores as sources and sinks. In: Anderson T (ed) Ecological studies, Vol 129. Springer-Verlag, Hong Kong

Beltrami E, Cosper E (1993) Modeling the temporal dynamics of unusual blooms. In: Smayda TJ, Shimizu Y (eds) Toxic phytoplankton blooms in the sea. Elsevier, Amsterdam, Dev Mar Biol 3:731-736

Borkman DG, Pierce RW, Turner JT (1993) Dinoflagellate blooms in Buzzards Bay, Massachusetts. In: Smayda TJ, Shimizu Y (eds) Toxic phytoplankton blooms in the sea. Elsevier, Amsterdam, p 211-216

Bricelj VM, Lonsdale DJ (1997) Aureococcus anophagefferens: causes and ecological consequences of brown tides in U.S. mid-Atlantic coastal waters. Limnol Oceanogr 42: 1023-1038

Chau YK, Wong CS (1960) Oceanographic investigations in the northern region of the South China Sea off Hong Kong. Hong Kong Univ Fish J 3:1-25

Dahl E, Tangen K (1993) 25 years experience with Gyrodinium aureolum in Norwegian waters. In: Smayda TJ, Shimizu Y (eds) Toxic phytoplankton blooms in the sea. Elsevier, Amsterdam, p 15-22

Dortch Q, Maske M (1982) Dark uptake of nitrate and nitrate reductase activity of a red-tide population off Peru. Mar Ecol Prog Ser 9:299-303

ECOHAB (1995) The ecology and oceanography of harmful algal blooms. A national research agenda. ECOHAB Workshop Report. Woods Hole Oceanographic Institution, Woods Hole, MA

Elbrachter M, Qi Y (1998) Aspects of Noctiluca (Dinophyceae) population dynamics. In: Anderson DM, Cembella D, Hallegraeff GM (eds) Physiological ecology of harmful algal blooms. Springer Verlag, New York, p 315-336

EPD (Environmental Protection Department) (1998) Marine water quality in Hong Kong for 1997. Environmental Protection Department, Hong Kong Government, Hong Kong

Fraga S, Bakun A (1993) Global climate change and harmful algal blooms: the example of Gymnodinium catenatum on the Galician coast. In: Smayda TJ, Shimizu Y (eds) Toxic phytoplankton blooms in the sea. Elsevier, Amsterdam, p 59-66

Fraga S, Anderson DM, Bravo I, Reguera B, Steidinger KA, Yentsch CM (1988) Influence of upwelling relation on dinoflagellates and shellfish toxicity in Ria de Vigo, Spain. Estuar Coast Shelf Sci 27:349-361

Gomez FE, Figueiras FG, Arbones B, Villarino ML (1996) Short-time scale development of a Gymnodinium catenatum population in the Ria de Vigo (NW Spain). J Phycol 32: 212-221

GEOHAB (Global Ecology and Oceanography of Harmful Algal Blooms) (1998) Joint IOC/SCOR Workshop Report, October 13-17, 1998 Havreholm. Asian Natural Environmental Science Center, Tokyo

Hernandez-Becerril DU, Cortes-Altamirano R, Alonso R (2000) The dinoflagellate genus Prorocentrum along the coasts of the Mexican Pacific. Hydrobiologia 418: $111-121$

Hodgkiss IJ, Ho KC (1997) Are changes in N:P ratios in coastal waters the key to increased red tide blooms? Hydrobiologia 852:141-147

Holmes PR (1988) Tolo Harbour - the case for integrated water quality management in a coastal environment. J Inst Water and Environ Manage 2:171-179

Honjo T, Yamamoto S, Nakamura O, Yamaguchi M (1990) Annual cycle of motile cells of Gymnodinium nagasakiense and ecological features during the period of red tide development. In: Graneli E, Sundstrom B, Edler B, Anderson DM (eds) Toxic marine phytoplankton. Elsevier Science Publishers, New York, p 165-170

Horner RA, Garrison DL, Plumley FG (1997) Harmful algal 
blooms and red tides on the US west coast. Limnol Oceanogr 42:1076-1088

Iwata Y, Ishida M, Uchiyama M, Okuzawa A (1989) Relationship between vertical stability and the occurrence of Chattonella red tides in Harima Nada, Setonaikai. In: Okaichi T, Anderson DM, Nemoto T (eds) Red tides: biology, environmental science and toxicology. Elsevier Science Publishers, New York, p 145-148

Jimenez R (1993) Ecological factors related to Gyrodinium instriatum bloom in the inner estuary of the Gulf of Guayaquil. In: Smayda TJ, Shimizu Y (eds) Toxic phytoplankton blooms in the sea. Elsevier, Amsterdam, p 257-262

Konovalova GV (1999) Red tides and blooms of water in the Far Eastern seas of Russia and adjacent areas of the Pacific Ocean. Russ J Mar Biol 25:295-304

Lam CWY, Ho KC (1989) Red tides in Tolo Harbour, Hong Kong. In: Okaichi T, Anderson DM, Nemoto T (eds) Red tides: biology, environmental science and toxicology. Elsevier Science Publishers, New York, p 49-52

Levasseur M, Therriault JC, Legendre L (1984) Hierarchical control of phytoplankton succession by physical factors. Mar Ecol Prog Ser 19:211-222

Lindahl O (1993) Hydrodynamical processes: a trigger and source for flagellate blooms along the Skagerrak coasts? In: Smayda TJ, Shimizu Y (eds) Toxic phytoplankton blooms in the sea. Elsevier, Amsterdam, p 775-782

Maclean JL (1989) Indo-Pacific red tides, 1985-1988. Mar Pollut Bull 20:304-310

Monteiro PM, Largier JL (1999) Thermal stratification in Saldanha Bay (South Africa) and subtidal, density-driven exchange with the coastal waters of the Benguela upwelling system. Estuar Coast Shelf Sci 49:877-890

Nakamura Y (1998a) Growth and grazing of a large heterotrophic dinoflagellate, Noctiluca scintillans, in laboratory cultures. J Plankton Res 20:1711-1720

Nakamura Y (1998b) Biomass, feeding and production of Noctiluca scintillans in the Seto Inland Sea, Japan. J Plankton Res 20:2213-2222

NRC (National Research Council) (2000) Clean coastal waters: understanding and reducing the effects of nutrient pollution. National Academy Press, Washington, DC

Nixon SW, Granger SL, Taylor DI, Johnson PW, Buckley BA (1994) Subtidal volume fluxes, nutrient inputs and the brown tide - an alternate hypothesis. Estuar Coast Shelf Sci 39:303-312

Pitcher GC, Calder D (2000) Harmful algal blooms of the southern Benguela Current: a review and appraisal of monitoring from 1989 to 1997. S Afr J Mar Sci 22: 255-271

Pitcher GC, Horstman DA, Calder D (1993) Formation and decay of red tide blooms in the southern Benguela upwelling system during the summer of 1990/91. In: Smayda TJ, Shimizu Y (eds) Toxic phytoplankton blooms in the sea. Elsevier, Amsterdam, p 317-322

Probyn TA, Pitcher GC, Monteiro PMS, Boyd AJ, Nelson G (2000) Physical processes contributing to harmful algal blooms in Saldanha Bay. S Afr J Mar Sci 22:285-297

Qi Y, Zhang Z, Hong Y, Lu S, Zhu C, Li Y (1993) Occurrence of red tides on the coasts of China. In: Smayda TJ, Shimizu $\mathrm{Y}$ (eds) Toxic phytoplankton blooms in the sea. Elsevier, Amsterdam, p 43-46

Shirota K (1989) Red tide problem and countermeasures (2). Int J Aquat Fish Technol 1:195-293

Takahashi M, Hara Y (1989) Control of diel vertical migration and cell division rhythm of Heterosigma akashiwo by day and night cycles. In: Okaichi T, Anderson DM,
Nemoto T (eds) Red tides: biology, environmental science and toxicology. Elsevier Science Publishers, New York, p 265-268

Taylor FJR, Haigh R (1993) The ecology of fish-killing blooms of the chloromonad flagellate Heterosigma in the Strait of Georgia and adjacent waters. In: Smayda TJ, Shimizu Y (eds) Toxic phytoplankton blooms in the sea. Elsevier, Amsterdam, p 705-710

Tester PA, Steidinger KA (1997) Gymnodimium breve red tide blooms: initiation, transport, and consequences of surface circulation. Limnol Oceanogr 42:1039-1051

Velikova V, Moncheva S, Petrova D (1999) Phytoplankton dynamics and red tides (1987-1997) in the Bulgarian Black Sea. Water Sci Technol 39:27-36

Vila M, Camp J, Garces E, Maso M, Delgado M (2001) High resolution spatio-temporal detection of potentially harmful dinoflagellates in confined waters of the NW Mediterranean. J Plankton Res 23:497-514

Villarino ML, Figueiras FG, Jones KJ, Alvarez-Salgado XA, Richard J, Edwards A (1995) Evidence of in situ diel vertical migration of a red-tide microplankton species in Ria de Vigo (NW Spain). Mar Biol 123:607-617

Voltolina D, Brown LN, Robinson MG (1985) Vertical variations of the chlorophyll maximum during a red tide in a shallow lagoon. Estuar Coast Shelf Sci 21:817-822

Walker DR, Pitcher GC (1991) The dynamics of phytoplankton populations, including a red-tide bloom, during a quiescent period in St Helena Bay, South Africa. S Afr J Mar Sci 10:61-70

Walsh JJ, Steidinger KA (2001) Saharan dust and Florida red tides: the cyanophyte connection. J Geophys Res C 106: 11597-11612

Watanabe M, Kohata K, Kunugi M (1988) Phosphate accumulation and metabolism by Heterosigma akashiwo (Raphidophyceae) during diel vertical migration in a stratified microcosm. J Phycol 24:22-28

Watts JCD (1971) The hydrology of the continental shelf area south of Hong Kong. 1. Oceanographic observation for the year 1969. Hong Kong Fish Bull 2:51-57

Watts JCD (1973) Further observation on the hydrology of the Hong Kong territorial waters. Hong Kong Fish Bull 3: 9-35

Williamson GR (1970) The hydrography and weather of the Hong Kong fishing grounds. Hong Kong Fish Bull 1: 43-49

Wong PS (1989) The occurrence and distribution of red tides in Hong Kong-applications in red tide management. In: Okaichi T, Anderson DM, Nemoto T (eds) Red tides: biology, environmental science and toxicology. Elsevier Science Publishers, New York, p 125-128

Wong PS, Wu RSS (1987) Red tides in Hong Kong: problems and management strategy with special reference to the mariculture industry. J Shoreline Manage 3:1-21

Yamochi S (1989) Mechanisms for outbreak of Heterosigma akashiwo red tide in Osaka Bay, Japan. In: Okaichi T, Anderson DM, Nemoto $\mathrm{T}$ (eds) Red tides: biology, environmental science and toxicology. Elsevier Science Publishers, New York, p 253-256

Yin K, Harrison PJ, Goldblatt RH, Beamish RJ (1996) Spring bloom in the central Strait of Georgia: interactions of river discharge, winds and grazing. Mar Ecol Prog Ser 138:255-263

Yin K, Goldblatt RH, Harrison PJ, Clifford PJ, St. John MA, Beamish RJ (1997) Importance of wind and river discharge in influencing nutrient dynamics and phytoplankton production in summer in the Central Strait of Georgia. Mar Ecol Prog Ser 161:173-183 
Yin K, Harrison PJ, Chen J, Huang W, Qian PY (1999) Red tides during spring 1998 in Hong Kong: is El Niño responsible? Mar Ecol Prog Ser 187:289-294

Yin K, Qian PY, Chen JC, Hsieh DPH, Harrison PJ (2000) Dynamics of nutrients and phytoplankton biomass in the Pearl River estuary and adjacent waters of Hong Kong during summer: preliminary evidence for phosphorus and silicon limitation. Mar Ecol Prog Ser 194:295-305

Yin K, Qian PY, Wu MCS, Chen JC, Huang LM, Song XY,

Editorial responsibility: Otto Kinne (Editor),

Oldendorf/Luhe, Germany
Jian WJ (2001) Shift from P to N limitation of phytoplankton biomass across the Pearl River estuarine Plume during summer. Mar Ecol Prog Ser 221:17-28

Yung YK, Wong CK, Broom MJ, Ogden JA, Chan SCM, Leung Y (1997) Long-term changes in hydrography, nutrients, and phytoplankton in Tolo Harbour, Hong Kong. Hydrobiologia 352:107-115

Zhao H (1990) Evolution of the Pearl River Estuary. Ocean Press, Beijing (in Chinese)

Submitted: September 9, 2002; Accepted: September 9, 2003 Proofs received from author(s): October 15, 2003 